\title{
Varför får folk socialbidrag? Analys av \\ socialbidragstagandets bestämningsfaktorer
}

\author{
BJÖRN HALLERÖD
}

\begin{abstract}
Socialbidraget utgör en sista försörjningsutpost och dess omfattning är en indikator på övriga försörjningssystems tillkortakommande. Syftet är här att öka kunskapen om de faktorer som leder till bidragstagande samt i vilken grad dessa har förändrats mellan 1980- och 1990-talet. Framförallt är det arbetslösheten och i viss mån förekomsten av låga inkomster som skiljer de två årtiondena åt.
\end{abstract}

När CSA bildades år 1903 var kampen mot fattigdom den i allt överskuggande socialpolitiska frågan. Fattigdomsfrågan var dock inte ny och det fanns vid förra sekelskiftet en rad åtgärder som på det ena eller andra sättet, inte alltid så framgångsrikt, avsåg att minska de fattigas umbärande. Vid sidan av en rudimentär fattighjälp tillgreps bland annat utackordering, bortauktionering, rotegång och olika former av fattighus som metoder för att sörja för landets medellösa, något som belyses väl i flera av de övriga bidragen i denna volym. De flesta av dessa

Björn Halleröd är professor i sociologi vid Umeå universitet. åtgärder är sedan länge utrangerade från den socialpolitiska agendan. Det gäller dock inte för fattighjälpen även om själva begreppet inte längre är i bruk. Fattighjälp bytte i samband med sjösättandet av 1957 års socialhjälpslag namn till just socialhjälp. Efter ytterligare 25 år ersattes socialhjälpslagen med 1982 års socialtjänstlag och socialhjälpen bytte namn till socialbidrag. Under de hundra år som förflutit sedan bildandet av CSA har naturligtvis mycket förändrats. I början av förra seklet utgjordes fattighjälpstagarna främst av äldre som inte längre förmådde att försörja sig. I början av detta sekel är det framförallt yngre personer som får socialbidrag. Fram till 1945 blev 
fattighjälpstagare automatiskt omyndigförklarade och de fick inte gifta sig eller delta i allmänna val (Rauhut 2002). Idag betraktas socialbidrag som en social rättighet och att frånta bidragstagarna grundläggande civila och demokratiska rättigheter framstår som helt främmande. Trots uppenbara förändringar så har dock dagens socialbidrag samma grundläggande funktion som gamla tiders fattighjälp, nämligen att garantera försörjning åt dem som inte kan försörja sig via marknaden, inte fångas upp av välfärdsstatens övriga transfereringssystem och inte heller kan sörjas för inom familjen. Ökar andelen bidragstagare finns det därför anledning till oro eftersom det tyder på en samhällelig dysfunktion. Att det ofta finns skäl för oro framgår av Diagram 1 som visar hur stor andel av befolkningen som någon gång under året mottagit fattig- socialhjälp/ socialbidrag under åren 1900 till och med 2001. Det finns (minst) två saker som är värda att begrunda. För det första så spelar, åtminstone från 1920-talet och framåt, de makroekonomiska förhållandena stor roll för andelen hjälp/bidragstagare. Det sena 20-talets och tidiga 30-talets ekonomiska turbulens leder till en markant ökning av fattighjälpstagandet och de höga nivåerna kvarstår tills andra världskrigets slut. Under efterkrigstiden kan varje större lågkonjunktur avläsas, alltifrån det tidiga 70-talets ekonomiska avmattning och "oljekris» till 90-talets ekonomiska trauma.

\section{Diagram I.}

Andel fattighjälpstagare / socialhjälpstagare / socialbidragstagare 1900 - 2001.

\section{Fattig- socialhjälp / socialbidrag 1900 - 1999}

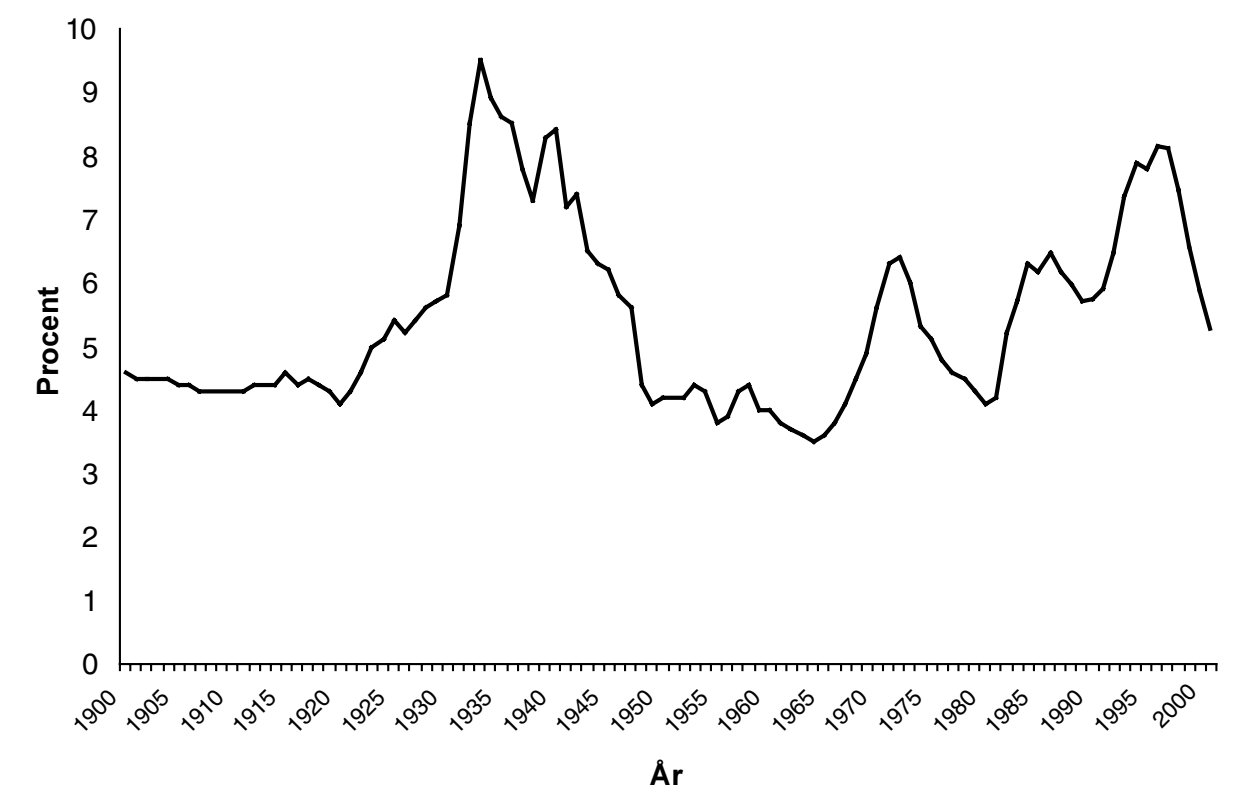

Björn Halleröd: Varför får folk socialbidrag? Analys av socialbidragstagandets bestämningsfaktorer. 
För det andra finns det under efterkrigstiden en trend mot ett allt mer omfattande hjälp/bidragstagande. Efter andra världskriget föll andelen fattighjälpsmottagare till nivåer som låg något under de som gällde $i$ mitten av 20-talet och i genomsnitt var det under 50- och 60-talen omkring 4 procent av befolkningen som fick hjälp. Motsvarande siffra för 70-talet var 5,3 procent, för 80-talet 5,6 procent och för 90-talet 7,1 procent. Det stigande antalet hjälp/ bidragstagare återspeglar naturligtvis ett kärvare ekonomiskt klimat. Det är dock värt att notera att bidragstagandet trendmässigt tycks öka även i goda tider då bidragstagandet också i högkonjunkturer under 70-, 80-, och 90-talen är mer omfattande än vad fallet var under 50- och 60-talen.

Syftet med denna artikel är att analysera en uppsättning faktorer som påverkade socialbidragstagandets omfattning under åren 1986-87 och 1996-98. Båda dessa tillfällen representerar en "vågkam» i socialbidragsstatistiken. År 1986 utgör kulmen i den ökning av bidragstagandet som inletts fyra år tidigare och år 1987 syntes en minskning av bidragstagandet. Åren 198687 var också arbetslösheten sjunkande, från en med efterkrigstidens mått mätt hög nivå, tillväxten steg och landet var på väg in i den högkonjunktur som kännetecknade det sena 80-talet. Situationen åren 199698 var ytligt sett liknande. Arbetslösheten sjönk, om än långsamt, från sin kulmen år 1996 och tillväxten tilltog. Den ekonomiska kris som föregick denna utveckling var dock som allom bekant av helt andra dimensioner än lågkonjunkturen i början av 80-talet. En för svenska förhållanden skyhög arbetslöshet, en bruttonational- produkt som var sjunkande under tre år i rad, 1991-93, åtstramningar inom de flesta trygghetssystem (inklusive socialbidraget), höjda skatter och höga realräntor bidrog till att sätta många hushåll under svår ekonomisk press. Samtidigt med de ekonomiska svårigheterna bidrog händelser utanför landets gränser till relativt stort inflöde av flyktingar och asylsökande som helt naturligt mötte stora svårigheter att etablera sig på arbetsmarkanden. En effekt av 90-talets djupa kris var att socialbidragstagandets omfattning närmade sig de nivåer som fattighjälpen hade under 1930-talet. Den grundläggande fråga som skall resas här är vilka förhållanden som orsakar socialbidragstagandet och om dessa förhållande förändrades i och med 90-talskrisen.

De orsaker till förändring av socialbidragstagandets omfattning som skall analyseras kan teoretiskt hänföras till tre nivåer: strukturell nivå, välfärdsstat och individuella faktorer. De aspekter som kommer att behandlas på strukturell nivå är förekomsten av arbetslöshet och demografisk sammansättning vad gäller ålder, kön, hushållssammansättning och nationell bakgrund. På välfärdsstatsnivå skall individernas beroende av transfereringar vid sidan av socialbidraget studeras. Här är det tre hypoteser som står i fokus. För det första att socialbidragstagare i stor utsträckning är beroende av andra typer av transfereringar för sitt uppehälle och därmed känsliga för förändringar i transfereringssystemen i stort. För det andra att en orsak till bidragstagande är att individer med låga inkomster inte får några andra transfereringar alls, det vill säga att de faller igenom de mer generella skyddsnäten. För det tredje att det finns ett 
nära samband mellan de två behovsprövade transfereringarna bostadsbidrag och socialbidrag. På individuell nivå är det resurser i form av hälsa och utbildning som kommer att undersökas. Dessutom kommer ett högt beroende av transfereringar i åldersskikt där det inte finns anledning att förvänta sig ett sådant att betraktas som en indikator på personliga egenskaper. Det finns naturligtvis en mängd andra individuella egenskaper som kan förklara varför antalet socialbidragstagare ökar eller minskar, en sådan är exempelvis benägenheten att i en given situation söka bidrag. Det måste dock konstateras att denna studie har sina begränsningar och att kopplingen mellan attityder och bidragstagande inte kan studeras inom ramen för denna artikel.

Gemensamt för de faktorer som nämnts ovan är att de i förhållande till socialbidraget kan betraktas som externa, det vill säga förhållanden som skapar behov av ekonomiskt bistånd. Nu är socialbidragstagandets utbredning och orsaker inte bara beroende av extern påverkan utan även av de interna regler och den praxis som gäller för bidragsgivande. Det är känt att det på handläggningsnivå kan finnas stora individuella variationer (Hydén m.fl. 1995). I vilken mån dessa variationer på något sätt är systematiska så att de påverkar bidragstagandets omfattning och vilken typ av bidragssökande som får bidrag är svårt att sia om. Att praxis gällande de krav som ställs på de bidragssökande, främst de unga, har förändrats under 90-talet och även slagit igenom i den nya lagstiftning som gäller sedan 1998 är dock klart (Johansson 2000). Det är inte bara kraven som har stramats åt utan även bidragsnormen har blivit mindre generös och mer homogen via införandet av den så kallade riksnormen. Dessa interna förändringar påverkar givetvis både bidragstagandets omfattning och bidragstagarnas sammansättning, vilket ju också är ett av syftena med att genomföra dem. Hur socialbidragstagandet har påverkats av interna förändringar kommer dock inte att kunna analyseras här.

De indikatorer på extern inverkan som nämnts ovan kommer att diskuteras mer i detalj i avsnitt tre där också deras operationalisering och fördelning i undersökningspopulationen kommer att redogöras för. Den centrala frågan om hur indikatorerna påverkar risken för socialbidragstagande analyseras i det efterföljande avsnittet.

\section{Avgränsningar och datamaterial}

Då arbetslöshet spelar en central roll för analyserna har undersökningspopulationen avgränsats med avseende på ålder och försörjningssituation. Åldersspannet är begränsat till 20 till 64 år. Dessutom har alla som uppbär pension, och som därmed permanent har lämnat arbetsmarkanden, uteslutits. ${ }^{1}$ Alla empiriska resultat som redovisas nedan är baserade på denna population. Det betyder inte att de allra yngsta, de äldre och personer som av en eller annan anledning mottar pension är ointressanta ur ett socialbidragsperspektiv. Avgränsningen motiveras bara av att

1 Det finns visserligen en möjlighet för förtidspensionärer att återvända till arbetsmarknaden. Den faktiska omfattningen av sådant återvändande är dock negligerbar.

Björn Halleröd: Varför får folk socialbidrag? Analys av socialbidragstagandets bestämningsfaktorer. 
Tabell I.

Andel socialbidragstagare och antal observationer fördelade efter delpopulationer.

\begin{tabular}{l|cccc}
\hline & \multicolumn{2}{|c}{ Andel med socialbidrag } & \multicolumn{2}{c}{$N$ (ej viktat) } \\
\cline { 2 - 5 } & $1986-87$ & $1996-98$ & $1986-87$ & 1996-98) \\
\hline Undersökningspopulation & 5,1 & 7,3 & 7945 & $1 \mid 942$ \\
16-19 åringar & 4,0 & 4,1 & 788 & 1 | 33 \\
20-64 åringar med pension & 5,2 & 3,3 & 698 & 1080 \\
65 till 84 åringar & 0,8 & 1,2 & 2386 & 3294 \\
Totalt & 4,2 & 5,7 & $1 \mid 818$ & 17429 \\
\hline
\end{tabular}

dessa personer inte primärt är beroende av arbetsmarknaden för sitt uppehälle. Undersökningspopulationen består alltså av dem som förväntas försörja sig via arbetsmarknaden eller i vissa fall via studiemedel.

Data är hämtade från fem olika årgångar av SCB:s undersökning av levnadsförhållanden (ULF) (Häll and Vogel 1997). De aktuella årgångarna är 1986, 1987, 1996, 1997 och 1998. De fem undersökningarna har lagts samman så att de utgör två databaser; en för åren 1986-87 och en för 199698. ULF baseras på ett representativt urval av den svenska befolkningen i åldrarna 16 till 84 år. Data samlas in via besöksintervjuer och uppgifter om inkomster hämtas från inkomstregistren. Bortfallet i ULF är förhållandevis lågt och var för det första mättillfället 20,8 procent och vid det andra tillfället 22,3 procent. Data har viktats för att kompensera för kända diskrepanser mellan urvalsram och det faktiska samplet. Problemet är naturligtvis att det kan finnas icke kända skevheter i bortfallet och det är rimligt att anta att förekomsten av försörjningsproblem och andra svårigheter är större i bortfallet än bland de svarande. Försörjningssvårigheter kan sålunda under- skattas i de analyser som görs. Tabell 1 visar storleken på de båda databaserna och hur den avgränsade undersökningspopulationen skiljer sig åt gentemot andra delar av ULF-populationen beträffande socialbidragstagande. Av tabellen framgår att socialbidragstagandet är vanligast förekommande i undersökningspopulationen (undantaget personer med pension i samma åldersspann år 1986-87). Det är också i denna population som ökningen varit mest påtaglig.

\section{Socialbidragstagandets orsaksfaktorer}

\section{Demografiska förhållanden}

Att ungdomar, ensamstående föräldrar och invandrade personer är överrepresenterade bland socialbidragstagarna är känt sedan länge och är inget som i sig förändrats under de senaste årtiondena (Hammarstedt 2000; Salonen 2000). Demografiska förändringar kan därför påverka bidragstagandets omfattning genom att utsatta grupper blir större eller mindre. En sådan demografisk förklaring är dock knappast tillfredsställande om vi inte samtidigt vet 
vilka specifika förhållande som genererar bidragstagandet. Att visa att vissa demografiska kategorier är mer utsatta än andra är därför bara ett sätt att identifiera var i befolkningen försörjningsproblemen är störst dock utan att förklara varför de är störst just där.

Operationaliseringen av ålder eller kön är tämligen given. Hushållsvariabeln består som framgår av tabell 2 av fem kategorier, en av dessa, "bor tillsammans med förälder" kräver en närmare förklaring. Sverige skiljer sig från de flesta andra länder då ungdomar när de blir 18 år gamla räknas som eget hushåll, det vill säga i nästan alla fall som ensamstående utan barn, oavsett om de fortsätter att bo kvar hos sina föräldrar eller inte. Det är naturligtvis två helt olika saker att vara "ensamstående» hemma hos mamma och/eller pappa och att vara ensamstående på riktigt. Då ULF innehåller data som gör det möjligt att särskilja dessa grupper åt har så också gjorts. Även när det gäller nationell bakgrund har populationen delats upp i fem kategorier: svenskar, första generationens svenskar, invandrare, nordiska medborgare och utländska medborgare. Bakom dessa kategorier döljer sig följande operationaliseringar. Svenskar är födda i Sverige av icke invandrade föräldrar. Första generationens svenskar är födda i Sverige men har minst en invandrad förälder. ${ }^{2}$ Syftet med att särskilja denna grupp är att studera om de försörjningssvårigheter som ofta drabbar invandrare även lever kvar bland deras barn.

2 Denna kategori kallas ofta 2:a generationens invandrare vilket dock är en både felaktig och missvisande benämning eftersom det inte är fråga om invandrare, de är alla födda i Sverige.
Invandrare utgörs av svenskar som inte är födda i Sverige, det vill säga invandrade personer med svenskt medborgarskap. Nordiska medborgare är på grund av språklig och kulturell närhet samt inte minst den öppna nordiska arbetsmarknaden en speciell kategori. Utländska medborgare är alla andra utan svenskt medborgarskap.

De demografiska kategoriernas fördelning redovisas i tabell 2. Eftersom undersökningspopulationen är begränsad (se ovan) skiljer sig dess sammansättning från befolkningen i sin helhet. Sett till förändring över tid så har ensamhushållen ökat något samtidigt som en minskning skett bland samboende med barn samt "vuxna" barn som fortfarande bor tillsammans med sina föräldrar. Av åldersfördelningen framgår att populationen blivit något äldre över tid. Andelen svenskar och nordiska medborgare har minskar något. Den demografiska sammansättningen bland dem som fått socialbidrag ser inte oväntat radikalt annorlunda ut. Andelen under 25 år är till exempel drygt dubbel så stor bland bidragstagarna jämfört med hela populationen. Andelen ensamstående föräldrar är tre till fyra gånger så hög bland bidragstagarna och 1996-98 var utländska medborgare mer än sex gånger vanligare bland bidragstagarna jämfört med hela populationen. Sett över tid kan det noteras att andelen barnfamiljer bland socialbidragstagarna har minskat något. Det samma gäller för de yngre, det vill säga dem under 30 års ålder. Det är tydligt att bidragstagarna $i$ allt högre grad utgörs av personer med någon form av utländsk bakgrund.

I tabell 2, och senare också i tabell 3 , redovisas även hur stor andel av varje

Björn Halleröd: Varför får folk socialbidrag? Analys av socialbidragstagandets bestämningsfaktorer. 
Tabell 2.

Totala undersökningspopulationens fördelning, socialbidragstagarnas fördelning samt andel socialbidragstagare i olika grupper (procent).

\begin{tabular}{|c|c|c|c|c|c|c|}
\hline & \multicolumn{2}{|c|}{$\begin{array}{c}\text { Andel av } \\
\text { populationen }\end{array}$} & \multicolumn{2}{|c|}{$\begin{array}{l}\text { Andel av social- } \\
\text { bidragstagarna }\end{array}$} & \multicolumn{2}{|c|}{$\begin{array}{c}\text { Andel med social- } \\
\text { bidrag }\end{array}$} \\
\hline & 1986-87 & $1996-98$ & 1986-87 & $1996-98$ & 1986-87 & 1996-98 \\
\hline Kvinna & 49,0 & 48,7 & 52,0 & 52,4 & 5,4 & 7,9 \\
\hline Man & 51,0 & 51,3 & 48,0 & 47,6 & 4,8 & 6,8 \\
\hline Under 25 år & 13,6 & $1 \mid, 8$ & 24,4 & 26,7 & 9,2 & 17,4 \\
\hline $25-30 a ̊ r$ & 15,0 & 15,6 & 26,9 & 18,7 & 9,2 & 8,8 \\
\hline $31-40$ år & 27,1 & 26,0 & 28,9 & 31,0 & 5,5 & 8,7 \\
\hline $41-50$ år & 23,7 & 24,4 & 13,9 & 15,9 & 3,0 & 4,8 \\
\hline $51-64$ år & 20,5 & 22,8 & 6,0 & 7,7 & 1,5 & 2,5 \\
\hline Bor tillsammans med förälder & 6,3 & 5,1 & 5,5 & 6,3 & 4,4 & 9,0 \\
\hline Ensam utan barn & 18,7 & 21,1 & 31,6 & 32,9 & 8,6 & $\mid 1,4$ \\
\hline Ensam med barn & 3,9 & 4,8 & 16,7 & 15,2 & 22,1 & 23,3 \\
\hline Sambo utan barn & 30,6 & 30,8 & 11,4 & 12,6 & 1,9 & 3,0 \\
\hline Sambo med barn & 40,5 & 38,2 & 34,8 & 32,9 & 4,4 & 6,3 \\
\hline Svenskar & 85,3 & 82,6 & 66,7 & 56,1 & 4,0 & 5,0 \\
\hline Första generationens svenskar & 4,4 & 6,4 & 6,2 & 6,3 & 7,2 & 7,2 \\
\hline Invandrare & 4,5 & 5,1 & 6,2 & 10,7 & 7,2 & 15,3 \\
\hline Nordisk medborgare & 2,8 & 1,9 & 6,2 & 2,2 & 11,4 & 8,5 \\
\hline Utländsk medborgare & 3,1 & 4,0 & 14,6 & 24,7 & 24,4 & 45,3 \\
\hline Arbetslösa vid intervju & 3,5 & 11,3 & $18, \mid$ & 37,6 & 26,7 & 24,3 \\
\hline Arbetslösa utan ersättning & 2,0 & 4,2 & 10,2 & 27,2 & 26,5 & 47,5 \\
\hline $\begin{array}{l}\text { Arbetslösa under de senaste } \\
\text { fem åren }\end{array}$ & 17,1 & 30,5 & 51,4 & 70,7 & 15,0 & 16,6 \\
\hline Låg inkomst, inga transf. & 1,5 & 2,0 & 0,7 & 3,4 & 2,6 & 12,5 \\
\hline Mottagit bostadsbidrag & 9,8 & 14,2 & 41,4 & 60,2 & 21,7 & 31,3 \\
\hline Nedsatt arbetsförmåga & 15,3 & 15,0 & 27,4 & 25,7 & 9,2 & 12,5 \\
\hline Enbart grundskola & 27,3 & 16,0 & 38,1 & 25,4 & 7,2 & 11,6 \\
\hline Gymnasium högst 2 år & 35,9 & 34,1 & 38,3 & 32,1 & 5,5 & 6,9 \\
\hline Gymnasium minst 3 år & 11,9 & 18,0 & 9,2 & 26,1 & 4,0 & 10,6 \\
\hline Efter gym. högst 2 år & 14,6 & 17,2 & 9,2 & 10,7 & 3,2 & 4,5 \\
\hline Efter gym. minst 3 år & 10,3 & 14,6 & 5,2 & 5,7 & 2,6 & 2,8 \\
\hline
\end{tabular}


enskild grupp som får socialbidrag vilket ger information om hur risken att uppbära socialbidrag varierar mellan olika kategorier i befolkningen. Jag kommer dock inte att kommentera dessa uppgifter löpande i texten då denna frågeställning i detalj belyses i avsnittet "Analys av socialbidragstagandets riskfaktorer».

\section{Arbetslöshet}

Att arbetslöshet och socialbidragstagande är nära förknippat är ingen nyhet. På aggregerad nivå finns det ett väl etablerat samband dem emellan (Gustafsson 1984; Korpi 1971; Stenberg 1998). Att antalet socialbidragstagare ökade i samband med att arbetslösheten steg kraftigt i början av 90-talet är därför ingen överraskning. Att en ökad arbetslöshet leder till ett ökat socialbidragstagande betyder dock inte att de arbetslösa generellt löper en ökad risk att bli bidragstagare. Det stora inflödet av arbetslösa under 90-talet innebar att stocken av arbetslösa i en mening normaliserades. Den del bland de arbetslösa som på grund av sjukdom, missbruk eller andra omständigheter alltid har svårt att få ett jobb kom att utgöra en mindre andel av den totala arbetslöshetsgruppen. De arbetslösa blev kort sagt en mindre selekterad grupp i och med att en allt större andel av de arbetslösa tidigare hade varit fast förankrade på arbetsmarknaden och därmed också $\mathrm{i}$ arbetslöshetsförsäkringen (Åberg m fl 1997). Givet att den ersättning de arbetslösa får förmår att lyfta dem över socialbidragsnormen finns det inget självklart samband mellan arbetslöshet och socialbidragstagande. Samtidigt är det viktigt att differentiera bland de arbets- lösa (Strandh 2000). Arbetslösa som inte är berättigade till arbetslöshetsersättning tvingas av naturliga skäl ofta att söka socialbidrag för sin försörjning. Likaledes är det rimligt att anta att den som under en längre period har erfarit en omfattande arbetslöshet är mer ekonomiskt sårbar än den som endast varit drabbad en kortare period och vid ett enstaka tillfälle. För att i viss mån kunna ta hänsyn till differentieringen bland de arbetslösa har följande operationaliseringar gjorts. För det första har en kategori bestående av dem som i samband med ULFintervjun definierats som arbetssökande skapats. För det andra har den sammanlagda arbetslöshetstiden under de senaste fem åren använts som indikator. Den tredje kategorin omfattar dem som under det aktuella året varit arbetslösa men som inte uppburit arbetslöshetsersättning av något slag. Vad gäller denna kategori kommer en viss underskattning av den verkliga andelen att göras vilket har sin grund i att ULF-intervjuerna genomförs löpande under hela året. Det betyder i sin tur att sannolikheten att en given individ har varit arbetslös någon gång under undersökningsåret ökar ju senare på året intervjun genomförs. Samtidigt spelar arbetslöshetstidernas längd in; ju längre dessa i genomsnitt är desto mindre blir underskattningen. Att fler arbetslösa faller in i denna kategori 1996-98 än vad som var fallet 1986-87 kan därför till en viss del bero på att arbetslöshetstiderna förlängts. ${ }^{3}$

Som framgår av tabell 2 har andelen $\mathrm{i}$

3 Bland dem som var arbetslösa vid intervjutillfället var medianen för arbetslöshetstiden 14 veckor år 1986-87 och 34 veckor år 1996-98.

Björn Halleröd: Varför får folk socialbidrag? Analys av socialbidragstagandets bestämningsfaktorer. 
populationen med arbetslöshetsproblem ökat markant. Andel som var arbetslösa vid intervjun har tredubblats. Andel arbetslösa utan arbetslöshetsersättning och andel som varit utan arbete åtminstone någon gång de senaste fem åren har fördubblats. Den sistnämnda kategorin har inte bara vuxit i storlek utan det är även så att den sammanlagda arbetslöshetstiden har ökat från i genomsnitt 32 veckor år 1986-87 till 67 veckor åren 1996-98. ${ }^{4}$ Detta har satt sitt tydliga avtryck bland socialbidragstagarna bland vilka arbetslöshetsproblem är betydligt vanligare 1996-98 än vad det var tio år tidigare. Det bör dock påpekas att data bara talar om ifall en person varit arbetslös och fått socialbidrag under det undersökta året. Om arbetslösheten och socialbidragstagandet infallit under exakt samma tidsperiod kan inte avgöras även om det naturligtvis är troligt att så ofta är fallet.

\section{Transfereringar}

Socialbidraget utgör försörjningssystemens sista skyddsnät. Det betyder bland annat att socialbidragstagandets omfattning är direkt avhängigt av de övriga transfereringssystemens förmåga att komplettera arbetsmarknaden och garantera en försörjning för dem som inte kan försörja sig via marknaden. Grovt sett kan transfereringarna delas upp i tre kategorier. En första kategori är de som avser att uppväga för ett stort utgiftstryck. Barnbidrag är ett

4 Fördelningen inom gruppen är skev och medianvärdena är betydligt lägre. Åren 1986-87 var medianen 17 veckor och åren 1996-98 var den 38 veckor. typexempel på detta. För det andra finns det transfereringar som skall kompensera för inkomstbortfall som exempelvis arbetslöshetsförsäkring, sjukpenning och föräldrapenning. För det tredje finns det behovsprövade bidrag som utgår efter en individuell prövning. Bostadsbidrag och socialbidrag är exempel på sådana.

Under 90-talet genomfördes nedskärningar inom transfereringssystemen på bred front (Palme 2000). Hur dessa påverkat socialbidragstagandet är svårt att överblicka. De flesta studier som gjorts baseras på så kallade mikrosimuleringar av hur många hushåll som vid en given förändring faller under socialbidragsnormen (Bergmark 2000). Skattningar av denna typ är dock alltid osäkra eftersom de förutsätter att allt annat är lika samt att de som faller under bidragsnormen också söker bidrag. Båda dessa antagande är med all sannolikhet orimliga; en stor andel av dem med inkomster under socialbidragsnormen söker inte socialbidrag (Halleröd 1991, 2000), samtidigt är det rimligt att ändrade premisser för transfereringssystemen leder till beteendeförändringar bland dem som berörs, vilket inte så sällen är ett uttalat syfte. Salonen (1997) har dock gjort ett försök att i 15 kommuner studera hur 9 faktiska nedskärningar påverkat socialbidragens storlek. Resultatet visade på ett tydligt samband och att socialbidraget till stor del fick kompensera för de nedskärningar som gjorts. Det finns därför skäl att tro att en betydande del av de ökade kostnaderna för socialbidrag är ett resultat av nedskärningar i andra transfereringssystem. Det bör dock påpekas att det stora flertalet som påverkas av 
förändringar i transfereringssystemen inte är eller blir socialbidragstagare och att endast en mindre del av statens totala utgiftsminskning därför vältras över på socialbidragen.

I analyserna kommer ett sammanfattande mått på transfereringsberoende att användas. Måttet uttrycker hur stor del av den samlade inkomsten före skatt som utgörs av transfereringar. Observera dock att eventuellt socialbidrag har dragits bort både från inkomsterna och från transfereringarna.

\section{Transfereringsberoende $=$}

Hushållets positiva transfereringar

$\frac{\text { före skatt-socialbidrag }}{\text { Hushållets inkomst före skatt-socialbidrag }}$

De som får en stor del av sin inkomst från olika former av transfereringar har med stor säkerhet en utsatt försörjningssituation (observera att pensionärer inte ingår $\mathrm{i}$ populationen). Det är också troligt att de är mottagare av en mix av olika typer av transfereringar. Det betyder i sin tur stor känslighet för försämringar i transfereringssystemen, speciellt när dessa, såsom var fallet under 1990-talet, genomförs på bred front. Det är därför inte en djärv gissning att anta att högt transfereringsberoende innebär en hög risk för socialbidragstagande. Sänkta barnbidrag, minskade ersättningsnivåer och ett mer restriktivt bostadsbidrag borde också, allt annat lika, leda till att socialbidragstagandet bland dem med högt transfereringsberoende var större åren 1996-98 än vad det var 1986-87. Problemet är dock att allt annat inte är lika mellan de två mättillfällena. En effekt av den kraftigt ökade arbetslösheten är att fler människor har ett stort transfereringsberoende. ${ }^{5}$ Samtidigt kan vi anta att det bland 90-talets arbetslösa finns en relativt stor grupp som är berättigade till arbetslöshetsersättning. Det är alltså möjligt att inkomsterna bland dem med stort transfereringsberoende är högre under 90-talet jämfört med 80-talet beroende på att gruppen vid det senare tillfället är mindre selekterad. Samtidigt som transfereringsberoendet visar varifrån inkomsterna kommer så är måttet också en indikator på graden av sysselsättning. De som får alla sina inkomster från transfereringar lever i ett hushåll där såväl den intervjuade som, i förekommande fall, make(a) under undersökningsåret stått helt utan inkomster från sysselsättning.

De två första kolumnerna i tabell 3 visar fördelningen i populationen efter graden av transfereringsberoende. Vid båda mättillfällena är det över 50 procent av befolkningen som har ett transfereringsberoende under tio procent, det vill säga mindre än tio procent av deras inkomster utgörs av transfereringar. Att andelen med noll procents transfereringsberoende har ökat dramatiskt kan med största sannolikhet tillskrivas sjuklönereformen från 1992 vilken innebar att arbetsgivaren och inte försäkringskassan står för ersättningen under de 14 första sjukdagarna. Under 1997 och fram till april 1998 var dessutom sjuklöneperioden förlängd till 28 dagar. Den andra stora förändringen är att

5 Åren 1986-87 hade tolv procent av dem som var arbetslösa vid intervjutillfället ett transfereringsberoende som var över 90 procent. Motsvarande siffra för åren 1996-98 var knappt 30 procent.

Björn Halleröd: Varför får folk socialbidrag? Analys av socialbidragstagandets bestämningsfaktorer. 


\section{Tabell 3.}

Fördelning efter transfereringsberoende, medianinkomst och socialbidragstagande efter transfereringsberoende

\begin{tabular}{|c|c|c|c|c|c|c|c|c|}
\hline \multirow{2}{*}{$\begin{array}{l}\text { Transfer- } \\
\text { ringsbe- } \\
\text { roend i } \\
\text { procent }\end{array}$} & \multicolumn{2}{|c|}{$\begin{array}{c}\text { Andel av } \\
\text { populationen }\end{array}$} & \multicolumn{2}{|c|}{ Medianinkomst* } & \multicolumn{2}{|c|}{$\begin{array}{c}\text { Andel av } \\
\text { bidragstagarna }\end{array}$} & \multicolumn{2}{|c|}{ Andel med bidrag } \\
\hline & 1986-87 & $1996-98$ & $1986-87$ & 1996-98 & 1986-87 & $1996-98$ & 1986-87 & $1996-98$ \\
\hline 0 & 7,6 & 24,9 & 103351 & $134 \mid 38$ & 1,5 & 5,2 & 1,0 & 1,5 \\
\hline-10 & 48,6 & 26,0 & 105182 & $10779 \mid$ & 11,0 & 5,2 & 1,2 & 1,4 \\
\hline $10-20$ & 15,0 & 11,8 & 87518 & 95034 & 10,0 & 5,8 & 3,5 & 3,5 \\
\hline $20-30$ & 8,7 & 9,2 & 83126 & 91656 & $1 \mid, 8$ & 6,7 & 7,0 & 5,2 \\
\hline $30-40$ & 6,3 & 6,9 & 83631 & 87665 & 10,5 & 6,6 & 8,6 & 6,8 \\
\hline $40-50$ & 4,1 & 4,8 & 84612 & 84366 & 9,5 & 7,0 & $|2|$, & 10,3 \\
\hline $50-60$ & 3,3 & 3,1 & 82321 & 78928 & 11,3 & 5,5 & 17,9 & 12,5 \\
\hline $60-70$ & 1,7 & 2,5 & 76393 & 75498 & 5,0 & 5,1 & 15,3 & 14,4 \\
\hline $70-80$ & 1,5 & 2,1 & 71378 & 72678 & 6,8 & 6,5 & 24,1 & 21,8 \\
\hline $80-90$ & 1,0 & 1,7 & 72969 & 66645 & 6,3 & 4,6 & 31,3 & 18,9 \\
\hline $90-100$ & 2,2 & 6,9 & 60458 & 55743 & 16,3 & 41,9 & 38,0 & 42,8 \\
\hline
\end{tabular}

* Hushållets ekvivalenta disponibla inkomst minus eventuellt socialbidrag uttryckt i 1998 års penningvärde

andelen som hade mer 90 procents transfereringsberoende var tre gånger så stor 1996-98 jämfört med 1986-87. Kolumn tre och fyra visar medianvärdet för den ekvivalenta disponibla inkomsten minus eventuellt socialbidrag (1998 års penningvärde) fördelad efter transfereringsberoende. Här kan vi se att de som hade under 40 procents transfereringsberoende år 1996-98 hade högre inkomster än motsvarande grupp hade år 1986-87. Bland dem med högre transfereringsberoende var förhållandet $i$ stort sett omvänt. Det kan alltså konstateras att inflödet av arbetslösa inte lett till att inkomsterna bland dem med högt transfereringsberoende har ökat. I vilken grad detta beror på 90-talets nedskärningar eller på att gruppen med högt bidragsberoende har förändrats är för närvarande okänt.
Klart är dock att kopplingen mellan högt transfereringsberoende och låga inkomster har stärkts över tid vilket i sin tur innebär att de med högt transfereringsberoende inte utgör en mindre selekterad grupp under 90-talet, åtminstone inte vad gäller inkomst. Trots att det finns ett tydligt samband mellan transfereringsberoende och disponibel inkomst så bör det framhållas att korrelationen mellan dem båda är högst måttlig (korrelationskoefficienten var 0,29 för åren 1986-87 och 0,33 för åren 1996-98). Transfereringsberoende kan med andra ord inte ses som en approximation av inkomst.

Kolumnerna fem och sex i tabell 3 visar hur socialbidragstagarna fördelar sig efter graden av transfereringsberoende. Det kan konstateras att fördelningen är 
ganska jämn men att personer med ett mycket högt bidragsberoende är klart överrepresenterade. Speciellt gäller detta vid det senare mättillfället då nästan 40 procent av alla bidragstagare får mer än 90 procent av sina övriga inkomster från andra typer av transfereringar. Det vill säga att för en stor del av bidragstagarna så spelade arbetsmarknadsinkomster en mycket liten roll. Att många socialbidragstagare i huvudsak får sina inkomster från andra transfereringar är helt i linje med antagandet att socialbidragstagare inte bara är beroende av socialbidrag utan också i stor utsträckning av andra typer och transfereringar. Det betyder i sin tur att de är känsliga för utformningen av andra transfereringssystem, något som inte minst verifieras av Salonens (1997) analyser. Det är också alldeles tydligt att de flesta socialbidragstagare inte totalt faller igenom de övriga transfereringssystemen samtidigt som dessa uppenbarligen inte ger ett adekvat inkomstskydd.

Även om många socialbidragstagare är beroende av andra transfereringar kan det inte uteslutas att personer som har en låg inkomst men som inte mottar några transfereringar alls också har en utsatt position. Det är bland dessa som de med problem att försörja sig via marknaden och som samtidigt faller igenom välfärdsstatens generella skyddsnät återfinns. För att kunna skatta betydelsen av kombinationen låg inkomst och inga transfereringar har en indikator skapats som diskriminerar dem som återfinns i de två lägsta inkomstdecilerna samtidigt som deras transfereringsberoende är noll. Som framgår av tabell 2 är det en mycket liten andel av undersökningspopulationen som uppfyller båda dessa kriterier. Åren 1986-87 är det också en försvinnande liten del av socialbidragstagarna som återfinns i gruppen. Värt att notera är dock att även om det bara är knappt 4 procent av bidragstagarna som år 1996-98 har låga inkomster och inget transfereringsberoende så är det fråga om en markant ökning som tyder på att vissa faller genom de övriga skyddsnäten.

Bland de transfereringar som utgår till hushållen spelar bostadsbidraget en speciell roll då detta är behovsprövat i relation till hushållets inkomst. Det betyder att det med nödvändighet råder en stor överlappning mellan socialbidragstagande och mottagande av bostadsbidrag. Samtidigt får förändring av bostadsbidragen direkta återverkningar på socialbidragstagandet (Salonen 1997). Det är dock problematiskt att jämföra bostadsbidraget över tid eftersom reglerna ofta ändrats. Under åren 1986 och 1987 begränsades rätten till bostadsbidrag till endast barnfamiljer. År 1988 reformerades systemet igen och bostadsbidrag kunde nu uppbäras även av ungdomar under 29 års ålder. I början av 90-talet ändrades reglerna så att även ensamstående och samboende utan barn över 29 års ålder fick rätt till bostadsbidrag. Denna regel togs bort år 1996 och under åren 1996-98 var det enbart barnfamiljer och ungdomar som kunde uppbära bostadsbidrag. Den markanta ökning av andelen bostadsbidragstagare som framgår av tabell 2 är främst en effekt av att även ungdomar under 29 års ålder kunde få bidrag vid det senare mättillfället. Det bör dock framhållas att det även bland barnfa-

Björn Halleröd: Varför får folk socialbidrag? Analys av socialbidragstagandets bestämningsfaktorer. 
miljerna skett en mindre ökning från 20,4 procent till 22,8 procent. ${ }^{6}$ Med tanke på att fler typer av hushåll var berättigade till bostadsbidrag är det ingen överraskning att fler socialbidragstagare fick bostadsbidrag vid det senare mättillfället.

\section{Individuella faktorer}

Att individuella faktorer spelar roll när enskilda individer söker socialbidrag är givet. Bidraget är utformat för att ta hand om dem vars försörjningsproblematik är så komplex att de mer generella transfereringssystemen inte räcker till. Själva tanken är också att det ekonomiska biståndet skall kombineras med socialtjänstens vidare sociala arbete vilket bland annat inbegriper att hjälpa den bidragssökande till en egen försörjning. Att utröna den totala effekten av alla individuella faktorer är naturligtvis ogörligt och här skall enbart tre aspekter att tas upp. För det första kommer betydelsen av hälsa att analyseras. Det kan dels förväntas att ohälsa generellt medför försörjningssvårigheter, dels att ett hårdnat arbetsmarknadsklimat med högre arbetslöshet och större krav på de arbetande gör att ohälsa är mer intimt förknippat med bidragstagande på 90-talet än

6 Samtidigt bör det framhållas att analyser visar att bostadsbidrag vid båda mättillfällena utbetalats till samtliga fem olika hushållstyper, det vill säga även till sådana hushåll som formellt inte var berättigade till bostadsbidrag. I vilken mån detta beror på en missmatch mellan utbetalande av bostadsbidrag och tiden för ULFintervjun, felaktig hushållsregistrering i ULF eller alternativt i samband med ansökan om bostadsbidrag kan inte avgöras här. på 80-talet. Till gruppen med dålig hälsa räknas de som angivit att de på grund av hälsoproblem har en nedsatt arbetsförmåga. Den andra indikatorn som skall användas är utbildning. 90-talet kris slog framförallt mot lågutbildade samtidigt som en omfattande utbildningsexpansion tog fart. Utifrån detta kan vi förutse två scenario. Enligt det första är det framförallt de med allra lägst utbildning som i ökad grad tvingats till bidragstagande då det dels är de okvalificerade jobben som försvunnit samtidigt som den ökade kadern med mer högutbildade besätter de nya mer kvalificerade jobben. Dessutom kan det antas att de ungdomar som idag inte går vidare till gymnasiet utgör en allt mer selekterad grupp. Ett andra scenario är att utbildningsexpansionen leder till att andelen högutbildade ökar i snabbare takt än vad arbetsmarkanden omvandlas. En situation där många kommer att vara "överutbildade" uppkommer då och hög utbildning kommer inte att vara en garant för god försörining (Åberg 2002). Enligt detta scenario kan vi förvänta oss att risken för socialbidragstagande främst kommer att öka bland dem som har mer än basal utbildning. Av tabell 2 framgår att en allt större andel av bidragstagarna har mer än en basal utbildning vilket initialt ger ett stöd åt det senare scenariot.

Den tredje indikatorn på individuella faktorer utgår från tanken om en interaktion mellan ålder och transfereringsberoende. Att ungdomar har ett högt transfereringsberoende är i sig inte märkligt då de många gånger är dåligt förankrade på arbetsmarknaden, har låga löner och ofta studerar, ett förhållande som i de flesta 


\section{Diagram 2.}

Transfereringsberoende fördelat efter ålder.

\section{Transfereringsberoende fördelat efter ålder}

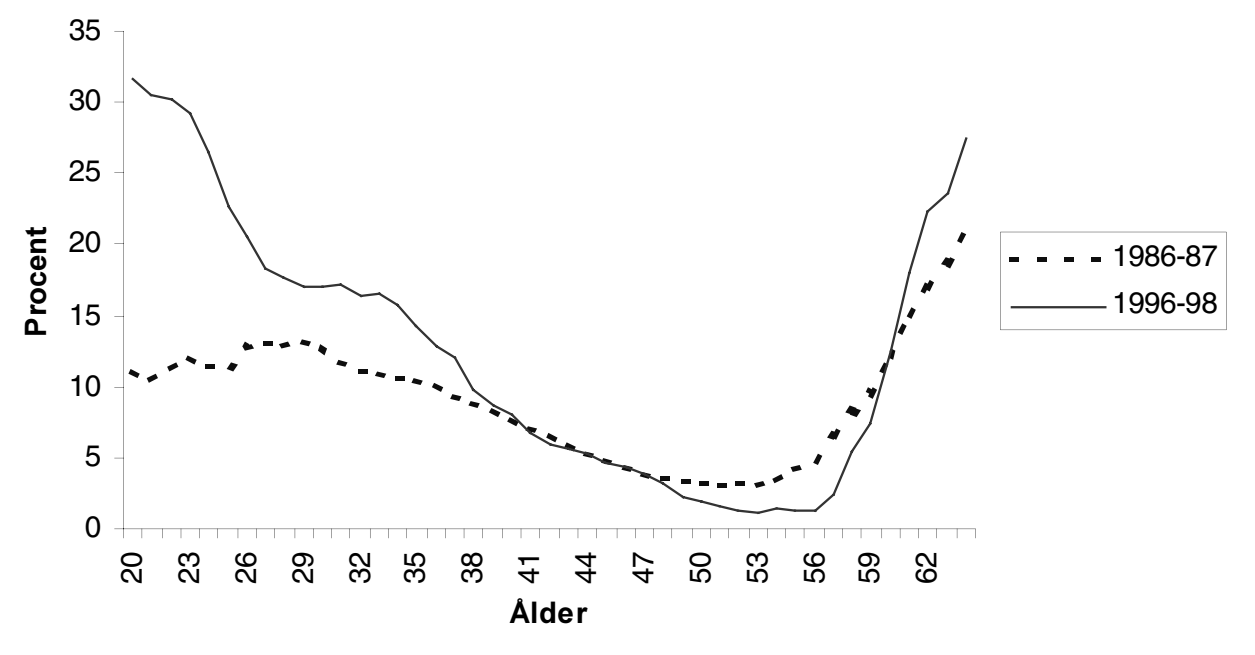

fall inte har någon långsiktig negativ effekt (Halleröd 2001). Personer som får barn, och därmed utnyttjar föräldrapenning, är också ofta relativt unga. Även bland den äldre delen av arbetskraften kan ett högt transfereringsberoende förväntas bland annat beroende på en förhöjd sjukskrivningsfrekvens och att längre perioder av arbetslöshet ofta kan föregå en slutlig pensionering (Stattin 1998). Bland den medelålders arbetskraften förväntas dock en fast förankring på arbetsmarknaden, relativt god ekonomi och följdriktligt ett lågt transfereringsberoende. Som framgår av diagram 2 är detta även ett empiriskt faktum; det är bland de äldre och de yngre som vi finner ett högt transfereringsberoende. Det bör dock framhållas att transfereringsberoendet bland de äldsta till viss del kan förstärkas av mätfel. De intervjuer som ligger till grund för ULF görs löpande under året vilket möjliggör att en person, helt korrekt, kan registreras som sysselsatt i ULF samtidigt som hon eller han senare under året pensioneras. En del av transfereringsberoendet bland de äldre kan därför trots allt ha sitt ursprung i pensionsinkomster. Trots att transfereringsberoendet generellt sett är lågt bland de "medelålders« så finns det naturligtvis även här individer som till stor del måste lita på transfereringar för sin försörjning. Det antagande som görs här är att orsaken till ett högt transfereringsberoende bland de medelålders är starkare knutet till individuella egenskaper än vad som är fallet bland de yngre och de äldre. Vilka dessa egenskaper är kan det naturligtvis bara spekuleras om men det är inte

Björn Halleröd: Varför får folk socialbidrag? Analys av socialbidragstagandets bestämningsfaktorer. 
helt orimligt att ohälsa, missbruk och allmänt trassliga sociala förhållanden spelar in. För att empiriskt testa antagandet har först en variable skapats som i brist på fantasi kallats för ıålderspik». I utgångsläget ger ålderspik värdet 23 till dem som är 42 år gamla. För de individer som är äldre eller yngre än 42 reduceras värdet med ett steg för varje års avvikelse. Det betyder att de yngsta och de äldsta i undersökningspopulationen, det vill säga 20 åringar och 64 åringar, får värdet 1 på variabeln ålderspik. Då utgångspunkten är att det är bland de medelålders som transfereringsberoendet antas vara lågt är det rimligt att tänka sig att smärre avvikelser från 42 års ålder inte spelar så stor roll samtidigt som betydelsen bör öka i takt med att vi rör oss mot allt större avvikelser. För att ta hänsyn till detta har ålderspik logaritmerats vilket konkret betyder att det har lite betydelse om en person är 37 istället för 42 samtidigt som skillnaden mellan 20 och 25 tillmäts betydligt större vikt. Interaktionsvariabeln skapas sedan genom att multiplicera transfereringsberoendet med logaritmen av ålderspik vilket gör det möjligt att mäta betydelsen av ålder i kombination med transfereringsberoende.

\section{Inkomst}

Demografiska faktorer, individuella egenskaper, arbetslöshet och transfereringssystemen är alla avgörande för individens disponibla inkomst som i sin tur är avgörande för om socialbidrag utges eller inte. Det kan därför tyckas givet att de som mottar socialbidrag också har de lägsta inkomsterna. Som framgår av tabell 4 så har också bidragstagarna betydligt lägre genomsnittsinkomst än vad andra har. Vi kan också se att gapet ökat betydligt mellan mättillfällena både på grund av att socialbidragstagarna blivit fattigare och på grund av att icke bidragstagare har blivit rikare. Socialbidraget skall ju kompensera för en låg inkomst och det är därför rimligt att dra bort socialbidraget från den disponibla inkomsten för att få en uppfattning om den situation som lett fram till bidragstagandet. Här ser vi att den ekonomiska marginaliseringen av bidragstagarna tilltagit över tid och det framgår också att det genomsnittliga bidraget har ökat i storlek.

Som visats i flera tidigare undersökningar är dock överlappningen mellan låg disponibel inkomst och socialbidragsta-

\section{Tabell 4.}

Medelvärde för ekvivalent disponibel inkomst (1998 årspenningvärde) i den totala undersökningspopulationen samt bland socialbidragstagare före och efter utbetalt socialbidrag

\begin{tabular}{l|cccc}
\hline & $\begin{array}{c}\text { Total ekvivalent } \\
\text { disponibel inkomst. } \\
\text { Ej socialbidrags- } \\
\text { tagare }\end{array}$ & $\begin{array}{c}\text { Total ekvivalent } \\
\text { disponibel inkomst } \\
\text { bland socialbidrags- } \\
\text { tagare }\end{array}$ & $\begin{array}{c}\text { Ekvivalent disponi- } \\
\text { bel inkomst bland } \\
\text { socialbidragstagare } \\
\text { - utbetalt socialbi- } \\
\text { drag }\end{array}$ & $\begin{array}{c}\text { Differens } \\
\text { (kolumn 2 }\end{array}$ \\
\hline$\AA r$ kolumn 3) \\
$\AA$ A 1986-87 $1996-98$ & 99948 & 76623 & 64475 & 12848 \\
\hline
\end{tabular}


gande låg (Halleröd 1991; 1995; 2000). De allra flesta med låga inkomster söker av olika anledningar inte bidrag och en del som söker får inte bidrag. Av dem som hade inkomster under 76623 kronor (medelinkomsten bland bidragstagarna) år 1986-87 var det enbart tio procent som fick bidrag. Av dem med inkomster under 67783 kronor år 1996-98 var det nästan 23 procent fick bidrag. Samtidigt finns det bidragstagare som har inkomster som ligger betydligt över de medelvärde som redovisas i tabell 4 och som även ligger betydligt över normen för socialbidrag. En viktig förklaring till detta är att bidragen baseras på den ekonomiska situation som råder när bidrag söks och betalas vanligen ut i relation till aktuell månad. Inkomststatistiken förs däremot på årsbasis. Detta leder i sig till en missmatch bland de bidragstagare som under året lyckas etablera en god ekonomi samt bland dem som under året hamnar på obestånd på grund av inkomstbortfall. Kontentan är dock att överlappningen mellan låg disponibel inkomst och socialbidragstagande är betydligt mindre än vad som intuitivt kan antas.

Sammanfattningsvis kan det konstateras att själva undersökningspopulationens sammansättning har förändrats något över tid. Det finns något fler äldre, ensamstående och även fler med utländsk bakgrund. Utbildningsnivån har höjts. Den stora förändringen är att fler är arbetslösa och att fler är starkt beroende av transfereringar för sin försörjning. Dessa förändringar har också slagit igenom bland socialbidragstagarna. Bidragstagarna har blivit något äldre, andelen med utländsk bakgrund har vuxit och bidragstagarna har blivit mer välutbildade. Arbetslöshet har blivit ett helt dominerande problem och beroendet av andra typer av transfereringar har ökat.

I och med att andelen socialbidragstagare har ökat från 4,2 procent åren 1986-87 till 5,7 procent åren 1996-98 så har givetvis sannolikheten att uppbära socialbidrag generellt sett ökat. Frågan är dock vilka faktorer som påverkar socialbidragsrisken mest och om dessa faktorer har förändrats över tid. Det faktum att andelen arbetslösa socialbidragstagare är betydligt större åren 1996-98 jämfört med åren 1986-87 betyder inte automatiskt att den relativa risken bland de arbetslösa att få socialbidrag ökat. Risken kan i själva verket ha minskat och att fler socialbidragstagare får bidrag kan vara en renodlad effekt av att det vid senare tillfället fanns fler arbetslösa. Vi kan också tänka oss en situation där en växande andel av de ensamstående föräldrarna får bidrag men att detta sker samtidigt som andelen bidragstagare bland andra hushållstyper ökar sitt bidragstagande relativt sett ännu snabbare. Överrisken bland de ensamstående föräldrarna skulle då minska över tid, trots att en allt större andel av dessa fick bidrag. Hur bidragsrisken för olika kategorier ser ut kommer att analyseras i det följande avsnittet.

\section{Analys av socialbidragstagandets riskfaktorer}

Den analytiska modellen för estimering av sannolikheten att uppbära socialbidrag utförs i flera steg. Först analyseras det bivariata sambandet mellan samtliga obe-

Björn Halleröd: Varför får folk socialbidrag? Analys av socialbidragstagandets bestämningsfaktorer. 


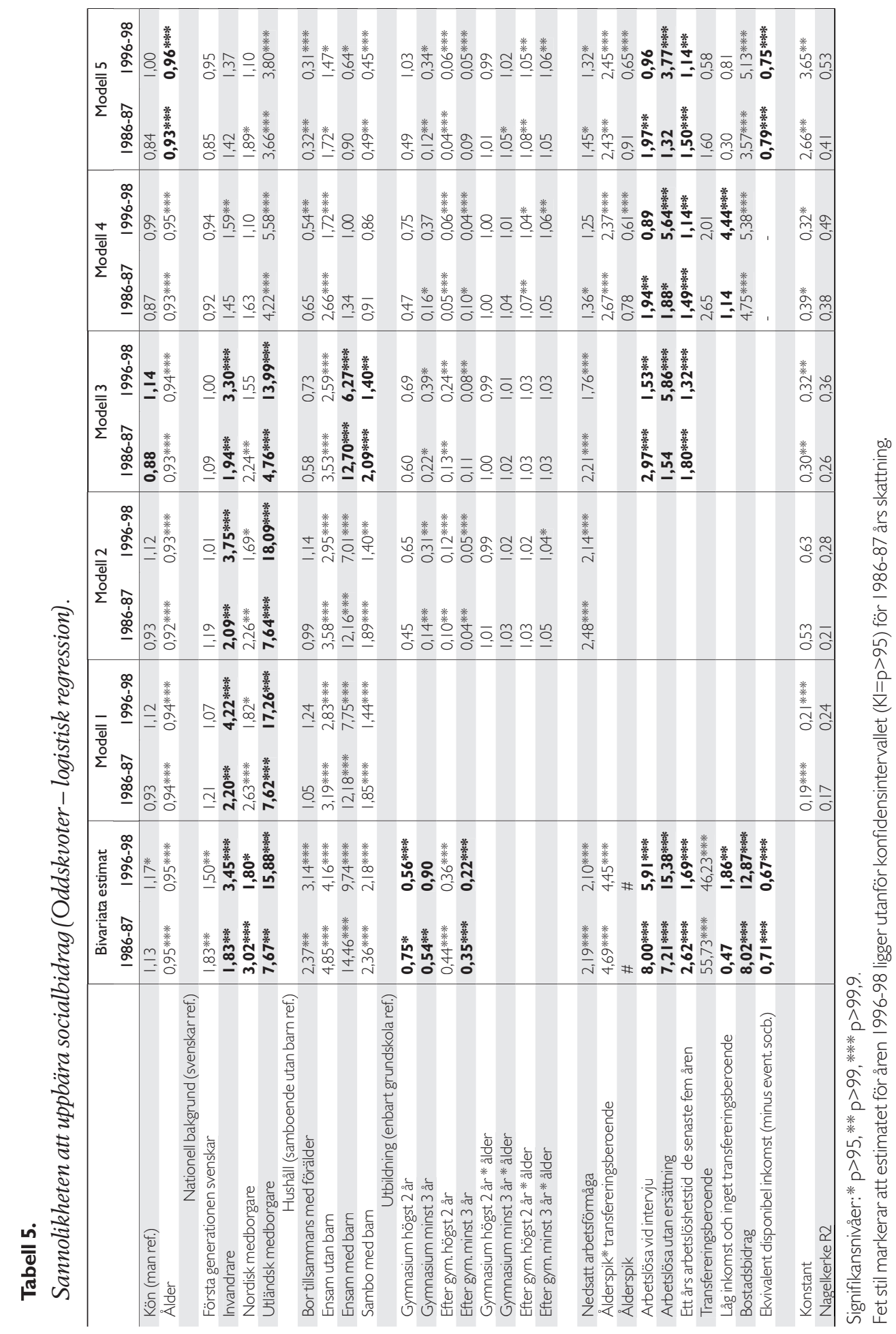

Socialvetenskaplig tidskrift nr 2-3 • 2003 
roende variabler och risken för socialbidragstagande. I nästa steg, i det som i tabell 5 refereras till som modell ett, genomförs en multivariat analys där effekten av de demografiska faktorerna, det vill säga kön, ålder, nationell bakgrund och hushållstillhörighet estimeras simultant. I modell två påförs de individuella faktorerna, i modell tre arbetslöshetsvariablerna, i modell fyra transfereringsvariablerna och slutligen i modell fem inkomstvariabeln. Sättet att genomföra analysen följer den så kallade effektöverföringsmodellen (Hellevik 1992) som i sin tur avser att estimera en kausal modell. Principen är att när nya variabler påförs så skall estimaten för de tidigare variablerna sjunka på grund av att en del av deras effekt är indirekt. Det kan exempelvis tänkas att många yngre får socialbidrag beroende på att de är mer exponerade för arbetslöshet än vad de äldre är. Ålder påverkar då risken att uppbära bidrag indirekt via arbetslöshet. Som varje uppmärksam läsare ser så är en del av de kausala antaganden som implicit görs i tabell 5 tämligen tvivelaktiga. Det antas till exempel att individuella faktorer påverkar hushållstillhörighet och inte tvärt om. Den analytiska modellen skall därför inte ses som ett uttryck för ett strikt kausalt antagande. Syftet är istället finna ett rimligt sätt på vilket de oberoende variablernas inbördes relation kan förstås.

Estimaten för de skattade sannolikheterna att uppbära socialbidrag presenteras i form av oddskvoter. De bivariata oddskvoter som redovisas i tabell 5:s två första kolumner ger för de flesta variabler i princip samma information som redovisas i de två sista kolumnerna i tabell 2. I tabell
2 kan vi till exempel se att 5 procent av svenskarna fick bidrag åren 1996-98, motsvarande siffra för utländska medborgare var 45,3 procent. Risken att få socialbidrag var alltså omkring 9 gånger högre (45,3/ $5,0=9,06)$ bland de utländska medborgarna än vad den var bland svenskarna. Den oddskvot som presenteras i tabell 5 anges dock till 15,88. Av detta kan vi dra slutsatsen att en oddskvot inte anger den relativa risken att, i det här fallet, uppbära socialbidrag. Vad är då en oddskvot? Som termen antyder är det fråga om kvoten mellan två odds. Bland utländska medborgare var det 45,3 procent som fick bidrag vilket samtidigt innebär att 54,7 procent inte fick bidrag. Oddset utgörs av kvoten mellan dessa tal, det vill säga sannolikheten att vara bidragstagare dividerat med sannolikheten att inte vara bidragstagare. I detta fall blir oddset cirka 0,83 , vilket är ett uttryck för att det nästan är lika sannolikt att en utländsk medborgare har bidrag som att hon/han inte har det (om så hade varit fallet, det vill säga om 50 procent av de utländska medborgarna fått socialbidrag blir oddset lika med 1). Oddset för svenskar att vara bidragstagare är under åren 1996-98 naturligtvis betydligt lägre och stannar vid 0,05 , det vill säga ett tal som på andra decimalen motsvara den proportion av svenskar som fick bidrag vilket i sin tur beror på att det var en liten andel av svenskarna som uppbar bidrag. I den logistiska regressionen i tabell 5 utgör svenskarna referensgrupp gentemot vilka de med annan nationell bakgrund jämförs. Oddskvoten för utländska medborgare är därför lika med kvoten mellan oddset för utländska medborgare och oddset för

Björn Halleröd: Varför får folk socialbidrag? Analys av socialbidragstagandets bestämningsfaktorer. 
svenskar, det vill säga $0,83 / 0,05 \approx 15,88$. ${ }^{7}$ Av detta följer att oddskvoten blivit 1 om bidragstagandet varit lika vanligt $i$ både grupperna. Varför då krångla till det hela genom att använda oddskvoter? I en bivariat analys är det egentligen överflödigt att uttrycka sannolikheter i termer av oddskvoter. I multivariata analyser är det däremot nödvändigt att använda oddskvoter eftersom de uttrycker relationer mellan oberoende variabler som inte påverkas av hur dessa kombineras med varandra vilket i princip är det enda sättet att isolera de enskilda variablernas effekter och göra analyserna överskådliga (Ribe 1999).

Det första vi ser i tabell 5 är att kvinnor har en större sannolikhet än män att uppbära socialbidrag. Oddset för kvinnor åren 1986-87 är 1,13. Estimatet är dock inte signifikant, det vill säga det kan inte med rimlig säkerhet sägas att oddset inte är lika med ett i befolkningen. Estimatet för 199698 är något högre och vid detta mättillfälle är det statistiskt säkerställt att kvinnor, i förhållande till män, löper en överrisk att vara socialbidragstagare. Det faktum att skillnaden mellan kvinnor och män inte var signifikant vid det första tillfället men väl vid det andra kan dock inte tas som intäkt för att könsskillnaderna med säkerhet ökat över tid. Orsaken är att estimatet för 199698 inte är signifikant skilt från estimatet för 1986-87. Åldersvariabeln i tabell 5 mäts som en kontinuerlig variabel vilket har betydelse inte minst för tolkningen av

7 Den noggranne läsaren finner naturligtvis att $0,83 / 0,05=16,6$ och inte 15,88 . Diskrepansen beror på att det krävs en stor mängd decimaler på de ingående proportionerna för att beräkna den korrekta oddskvoten. oddskvoten. Oddset för ålder är mindre än ett vilket betyder att sannolikheten att uppbära socialbidrag minskar för varje årskull i populationen.

Genom att studera de bivariata estimaten får vi en tydlig bild av vilka grupper som är över- eller underrepresenterade bland socialbidragstagarna. Samtliga med någon form av utländsk bakgrund löper en högre risk att motta bidrag jämfört med referensgruppen som utgörs av dem som här kallas för svenskar. Speciellt påtagligt är detta för dem med utländskt medborgarskap som år 1996-98 hade en oddskvot på nästan sexton. Bland invandrare och utländska medborgare har det också skett en signifikant ökning av bidragstagandet mellan de båda mättillfällena vilket i tabellen indikeras med fet stil. Bland de nordiska medborgarna har det samtidigt skett en minskning.

Alla hushållstyper avviker signifikant från referensgruppen som är samboende utan barn. Speciellt markant är detta för ensamstående föräldrar som år 1986-87 hade ett odds som var femton gånger så högt som referensgruppen samboende utan barn. Att även utbildning är relaterat till bidragstagande framgår av att alla med någon form av utbildning efter grundskola år 1986-87 hade lägre bidragsrisk än dem med enbart grundskola. Samma mönster men med ett viktigt undantag framträder vid det andra mättillfället. En tvåårig gymnasieutbildning $i$ det närmaste halverar bidragsrisken och för dem med universitetsexamen är oddset bara en femtedel av oddset bland dem med bara grundskola. Båda dessa skattningar är vidare signifikant skilda från 1986-87 års estimat. Den stora skillnaden mellan åren gäller dock dem 
med treårigt gymnasium. År 1996-98 har personer i denna grupp i princip lika stor risk att vara bidragstagare som dem med enbart grundskola. Orsaken till denna utveckling står med all säkerhet att finna i relationen mellan utbildningsnivå och individernas ålder. Andelen som genomgår gymnasial utbildning har ökat över tid, samtidigt som alla gymnasieutbildningar har gjorts treåriga. I gruppen med treårigt gymnasium finns därför en stor heterogen grupp ungdomar och det är rimligt att det framförallt är bland dessa som socialbidragstagarna återfinns.

Nedsatt arbetsförmåga på grund av ohälsa mer än fördubblar risken för bidragstagande vid båda mättillfällena. Det är dock inte så att överrisken bland dem med nedsatt arbetsförmåga har ökat över tid. Den tredje indikatorn på det som här har definierats som individuella egenskaper är en interaktionseffekt mellan wålderspik", det vill säga åldersavvikelsen från 45 års ålder, och transfereringsberoende. Som framgår av kolumnerna ett och två finns det en tydlig sådan effekt. ${ }^{8}$ Att vara medelålders och till stor del beroende av transfereringar har en helt annan betydelse än vad som är fallet bland de äldre och de yngre.

Arbetslöshetsindikatorerna har som väntat betydande effekt vid båda mättillfällen. Samtidigt finns det tydliga skillnader mellan 1986-87 och 1996-98. Alla som vid ULF-intervjun stod utan arbete hade en förhöjd risk att vara bidragstagare. Risken var dock klart lägre 1996-98 vilket kan ses

8 Det bör noteras att estimatet inte är en renodlad bivariata skattning utan baseras på en modell som även innehåller transfereringsberoende och ålderspik. som ett tecken på den "normalisering" av de arbetslösa som den kraftigt höjda arbetslösheten lett till. Det samma gäller effekten av arbetslöshetserfarenhet. En mycket större grupp har under 1990-talet erfarit arbetslöshet och det är rimligt att anta att detta för många var en övergående episod som inte lett till långsiktiga försörjningsproblem. Den stora skillnaden mellan mättillfällena finns dock bland dem som varit arbetslösa men som inte fått någon arbetslöshetsersättning. Varför effekten av avsaknad av bland annat a-kassa bland de arbetslösa ökat så mycket är naturligtvis svårt att säga. Det finns i princip två orsaker till att arbetslösa inte har ersättning från a-kassa. Den arbetslöse kan bli utförsäkrad efter en längre tids arbetslöshet. Det finns dock lite som talar för att detta rent volymmässigt är något större problem. Däremot tycks det vanligare att människor ställs utanför a-kassan på grund av att de inte klarat av kvalifikationskraven (Halleröd 1991). I samband med det är det viktigt att komma ihåg att kvalifikationskraven har skärpts under 90-talet.

Att kopplingen mellan transfereringsberoende och socialbidragstagande är starkt visas med all tydlighet då oddset är ungefär 50 gånger högre bland dem som får alla sina inkomster från transfereringar jämfört med dem helt utan transfereringsinkomster. Åren 1996-98 finns det även en förhöjd risk bland dem med låga inkomster men som trots det inte får några transfereringar. Det finns vid båda mättillfällena en klar koppling mellan bostadsbidragstagande och socialbidragstagande. Den sista variabel för vilken bivariata estimat anges är hushållens ekvivalenta disponibla inkomst

Björn Halleröd: Varför får folk socialbidrag? Analys av socialbidragstagandets bestämningsfaktorer. 
minus eventuellt socialbidrag. Variabeln uttrycker inkomsten i 10 000-tals kronor och visar tydligt att en ökning av inkomsten minskar risken för socialbidragstagande, något som knappast är förvånande. Det bör dock påpekas att sambandet försvagas påtagligt om den totala disponibla inkomsten, det vill säga inklusive eventuellt socialbidrag, används. ${ }^{9}$

\section{Multivariat analys}

Utgångspunkten för tolkningen av de multivariata analyserna tas i modell fem. Här kan vi för det första se att det inte finns någon signifikant skillnad mellan kvinnor och män. Den främsta orsaken till detta är att de allra flesta ensamstående föräldrar är kvinnor och skillnaden mellan könen upphör att vara signifikant redan i modell ett. Estimatet för ålder är tämligen okänsligt för hur modellen specificeras och vilka år som studeras. Detta är i sig ett intressant resultat eftersom det visar att åldersskillnaderna består även efter det att de övriga variablerna är kontrollerade för. Det tyder på att äldre människor har en större förmåga än yngre att klara sin försörjning oberoende av hushållssituation, utbildning, hälsa, arbetslöshet, transfereringsberoende och inkomst. Det kan i sin tur bero på åtminstone tre saker. För det första kan deras bättre erfarenhet göra att de har större förmåga att hantera en ansträngd hushållsekonomi. För det andra har äldre människor haft längre tid på sig att bygga

9 Om socialbidragen räknas in i den disponibla inkomsten sjunker effekten och oddset blir 0.80 för år 1986-87 respektive 0.77 för 199698. upp en ekonomisk buffert, en egenskap som inte fångs upp av de variabler som ingår i denna analys. En tredje möjlighet är att äldre människor i högre grad finner socialbidragstagande stigmatiserande än vad yngre gör och att de därför är mer benägna att klara ekonomiska påfrestningar på egen hand. En detalj som kan vara värd att notera är att variabeln ålderspik i modell fem har ett odds under ett och att estimatet är signifikant för åren 1996-98. Tolkningen av detta estimat måste göras simultant med tolkningen av estimatet för ålder. Den konkreta innebörden är att modellen antar en avtagande effekt av ålder, det vill säga att det är större skillnad mellan en 22åring och 32-åring än vad det är mellan en 52-åring och en 62-åring vilket på det hela förefaller vara mycket rimligt.

I modell fem är det bara de utländska medborgarna och nordiska medborgare åren 1986-87 som skiljer sig från svenskarna. Anledningen till att första generationens svenskar hade en signifikant högre bidragsrisk beror på att gruppen är förhållandevis ung och effekten försvinner följaktligen när ålder och hushållssituation konstanthålls. Det går därmed inte att säga att socialbidragstagande i denna kategori har något att göra med att deras föräldrar invandrat. Bland de övriga med utländsk bakgrund är det arbetslöshet och i ännu högre grad det påföljande transfereringsberoendet i kombination med ålder och slutligen den låga inkomsten som förklarar en stor del av deras överrisk. Det vill säga de med utländsk bakgrund kommer inte in på arbetsmarknaden, de får transfereringar men inte i tillräcklig utsträckning vilket som effekt ger allt för låga inkomster. För 
de utländska medborgarna kvarstår dock vid båda mättillfällena en klar överrisk även efter kontroll för de övriga variablerna i modell fem. En möjlig förklaring till detta är att många av dessa saknar egna ackumulerade resurser och även i den mån de har ett socialt nätverk kan det misstänkas att även detta är ekonomiskt resurssvagt. Samtidigt befinner sig många utländska medborgare i en situation där de i princip skall återetablera sitt hushåll vilket leder till en förhöjd utgiftsbörda.

Av hushållskategorierna är det i modell fem enbart de ensamstående utan barn som har en överrisk jämfört med referensgruppen, de samboende utan barn. För de övriga gäller att, kontrollerat för de övriga faktorerna, bidragsrisken är lägre än för referensgruppen. För barnfamiljerna är det tydligt att det är låga inkomster kopplat till högt transfereringsberoende som är orsaken till att de oftare får socialbidrag än de samboende utan barn.

För att kontrollera samspelet mellan ålder och utbildning har i modell två interaktionen mellan dessa båda variabler skattats. Efter kontroll för både ålder och interaktionen mellan ålder och utbildning är de förändringar över tid som kunde observeras i den bivariata analysen inte längre signifikanta. Inte heller skiljer sig dem med tvåårigt gymnasium från dem med bara grundskola men i övrigt så innebär en högre utbildning en minskad risk för bidragstagande. Detta är ett mönster som i det stora hela håller i sig även i de efterföljande modellerna även om vissa förändringar i estimat och signifikansnivåer kan observeras allt eftersom fler variabler läggs till modellen. De skattade interaktionsef- fekterna är i huvudsak svagt positiva, det vill säga effekten av en högre utbildning tycks avklinga i takt med att populationen blir äldre. (Det innebär dock inte att en äldre med högskoleutbildning löper en högre risk eftersom det samtidigt finns en renodlad effekt av ålder.) Det är dock bara ett av interaktionsestimaten som är signifikant i modell 2. Det faktum att tre av estimaten är signifikant i modell 4 och fyra i modell 5 tyder på att det finns ytterligare interaktionseffekter mellan utbildning och inkomstsituationen. Statistiskt kan dock inte några sådana interaktioner säkerställas. Slutsatsen här, liksom i många andra studier (Halleröd 1999), är dock att högre utbildning lönar sig och att det på den punkten inte skett någon förändring över tid.

Nedsatt arbetsförmåga på grund av ohälsa uppvisar signifikanta effekter även i modell fem. Kontroll för inkomstsituationen innebär visserligen att estimaten försvagas, men inte att de försvinner. Här finns minst två möjliga förklaringar. Ohälsa kan i vissa fall leda till betydande utgifter i form av vård, mediciner och hjälpmedel. Ohälsa kan också vara förknippat med missbruk och andra omständigheter som försvårar hanterandet av den egna ekonomin. Att vara medelålders och ha ett högt transfereringsberoende antogs vara en indikator på individuella egenskaper. Detta verifieras också av analysen då effekten av denna interaktion är stabil och signifikant även efter det att arbetslöshet, transfereringsmottagande och inkomst har kontrollerats. Det är heller ingen skillnad i estimaten mellan mättillfällena vilket tyder på att detta är ett beständigt förhållande.

När det gäller de tre indikatorerna 
på arbetslöshet så har de alla tre förändrats signifikant över tid. Kontrollerat för inkomstsituationen så avviker inte de som var arbetslösa vid intervjun från de ej arbetslösa vid det senare mättillfället. Deras höga bidragsrisk beror på för låga inkomster och i samband med det ett högt transfereringsberoende. Detta var inte fallet år 1986-87 vilket rimligen kan tolkas som att de arbetslösa i en mer gynnsam arbetsmarknadssituation är en mer selekterad grupp med en mer komplex problembild. Resonemanget understöds av att estimatet för arbetslöshetserfarenhet också är signifikant lägre 1996-98 än vad det var 1986-87. Om arbetslösheten i sig har lägre effekt vid hög arbetslöshet så är inte detta fallet bland de arbetslösa som saknar arbetslöshetsersättning. Två tredjedelar av den ursprungliga överrisken i denna grupp är relaterad till demografiska och individuella faktorer. Det bör dock noteras att år 1996-98 kvarstår en betydande och signifikant effekt av arbetslöshet utan ersättning trots att inkomsten kontrolleras i modellen. Frågan är naturligtvis varför en överrisk kvarstår. En möjlig förklaring är att det bland de arbetslösa finns individer som under en del av året är arbetslösa utan ersättning. Under denna period har de ingen annan inkomstkälla än socialbidrag samtidigt som de har inkomster under övriga delar av året som räcker till att skapa en någorlunda rimlig årsinkomst.

Att transfereringsberoendets inverkan minskar efter kontroll för demografi, individuella egenskaper och arbetslöshet är ganska givet. Att minskningen är så dramatisk mellan de bivariata estimaten och estimaten i modell fyra beror dock i huvudsak på att interaktionseffekten mellan ålderspik och transfereringsberoende finns med i denna modell. ${ }^{10}$ Det är alldeles tydligt så att det beständiga sambandet mellan transfereringsberoende och socialbidragstagande är relaterat till ålder och att det är högt transfereringsberoende bland medelålders som spelar störst roll. Att effekten av interaktionsvariabeln kvarstår även efter kontroll av inkomst stärker antagandet att högt transfereringsberoende bland personer i medelåldern är en indikator på mer komplexa individuella problem.

Kopplingen mellan att ha låg inkomst men ändå inte ha någon transfereringsinkomst och socialbidragstagande försvinner efter kontroll av inkomst vilket tycks vara rimligt. Däremot kvarstår, något förbryllande, kopplingen mellan socialbidragstagande och bostadsbidragstagande även i modell fem. Förbryllande eftersom bostadsbidraget borde vara en funktion av inkomsten. En möjlig förklaring till detta är att personer som söker socialbidrag även uppmanas, och kanske får hjälp med, att söka bostadsbidrag. Den sista variabeln i analysen är den ekvivalenta disponibla inkomsten minus eventuellt socialbidrag. Även om kontroll för de övriga variablerna reducerar effekten något så kvarstår det

10 I en begränsad modell där bara transfereringsberoende, ålderspik och interaktionen dem emellan analyseras sjunker den renodlade effekten av transfereringsberoende till 2,27 respektive 1,74 samtidigt som båda estimaten mister sin signifikans. Om interaktionen mellan ålderspik och transfereringsberoende lyfts ut ur modell 4 blir effekten av transfereringsberoende 19,84 för åren 1986-87 och 12,39 för 1996-98. 
mesta och låga inkomster är helt naturligt en central aspekt för att förstå bidragstagandet.

\section{Slutsatser}

Analyserna ovan har på ett grundläggande plan visat att risken för att uppbära socialbidrag varierar kraftigt mellan olika kategorier i befolkningen. En stor del av den variationen kan förstås utifrån position på arbetsmarkand och som en direkt följd av detta en låg inkomst. Den multivariata analysen visar visserligen att utländska medborgare, ensamstående och lågutbildade löper en förhöjd risk att vara socialbidragstagare även efter det att kontroll för de övriga oberoende variablerna gjorts. Det mesta av de stora skillnader som framkom i den bivariata analysen är dock borta. Viktigt är också att det finns en betydande stabilitet över tid. Att risken för bidrag har ökat signifikant bland personer med utländsk bakgrund beror på den försämrade arbetsmarknadssituationen. Efter kontroll för denna återstår inte några skillnader mellan undersökningstillfällena. De faktorer som här har kallats individuella är också stabila över tid. Personer med nedsatt arbetsförmåga och medelålders med högt transfereringsberoende har större sannolikhet än andra att uppbära bidrag. Det är dock inte så att överrisken i dessa grupper har ökat. Utifrån dessa empiriska data kan en av de frågor som ställdes $\mathrm{i}$ inledningen besvaras med ett nej - de förhållanden som leder fram till socialbidragstagande har inte förändrats mellan mättillfällena; det är istället de problematiska förhållandenas omfattning som förändrats och framförallt då arbetslösheten.

Kopplingen mellan arbetslöshet och socialbidragstagande har stärkts i och med 90-talets lågkonjunktur. Det var också tydligt att låga inkomster till mycket stor del förklarar varför arbetslösa får bidrag, vilket knappast i sig är förvånande. Samtidigt minskade bidragsrisken paradoxalt nog bland de arbetslösa. Orsaken till detta står förmodligen att finna i en selektionseffekt. Under den relativt låga arbetslösheten åren 1986-87 utgjordes de arbetslösa med all säkerhet av en mer selekterad grupp där arbetslöshet ofta var ett av flera problem. Den höga arbetslösheten under 90-talet innebar att en allt större andel av de arbetslösa utgjordes av individer som enbart hade ett problem, nämligen det att de var arbetslösa och på grund av det hade otillräckliga inkomster. En slutsats är därför att socialbidraget i ökad utsträckning kommit att fungera som ett renodlat inkomstskydd vid arbetslöshet. Detta intryck stärks av det faktum att sambandet mellan låg inkomst och socialbidragstagande har stärkts över tid. En speciell position intas dock av de arbetslösa som står utan arbetslöshetsersättning. Även efter kontroll av inkomster kvarstår en överrisk för denna grupp vilket reser frågan om vilka förhållanden som genererar socialbidragstagande. Det samma gäller för ensamstående, personer med låg utbildning, nedsatt arbetsförmåga och medelålders med ett högt transfereringsberoende. Det är dock en fråga som inte kan besvaras inom ramen för denna studie. Vad som dock kan sägas är att överrisken bland dessa grupper på det stora hela inte har förändrats över tid.

Björn Halleröd: Varför får folk socialbidrag? Analys av socialbidragstagandets bestämningsfaktorer. 
Att isolera betydelsen av enskilda faktorer är i sig intressant eftersom det är ett sätt att öka vår kunskap om socialbidragstagandets orsaker. Hos faktiskt existerande individer återfinns dock alltid en kombination av egenskaper. Som en illustration av hur kombinationen av egenskaper påverkar socialbidragsrisken redovisas i Tablå 1 den skattade risken att uppbära socialbidrag för olika »idealtyper». För en högutbildad 45-årig svensk, samboende utan barn och med relativt god inkomst är bidragsrisken negligerbar. Antar vi att det är fråga om en utländsk medborgare med i övrigt liknande egenskaper ökar den skattade risken något, dock inte mycket. När olika egenskaper som ökar risken för bidragstagande kombineras ökar risken högst påtagligt för att till slut närma sig 100 procent. Det är inte den ordning som de olika egenskaperna läggs på som är avgörande för skattningen utan det faktum att riskhöjande faktorer ackumuleras. Det faktum att sannolikheten att uppbära socialbidrag ökar mycket snabbare i takt med att egenskaper ackumuleras åren 1986-87 jämfört med 1996-98 är ytterligare en indikator på att ogynnsamma förhållanden diskriminerar hårdare $i$ relativt goda tider när både dessa förhållanden och socialbidragstagandet i sig är ovanligare. Därmed kan också slutsatsen dras att socialbidraget fullgör sin funktion som välfärdsstatens sista utpost och som ett stöd för dem med en mer komplex problembild på ett bättre sätt i ekonomiskt goda tider. I samband med 90-talets lågkonjunktur och

\section{Tablå I.}

Skattade risker att uppbära socialbidrag i sex olika "idealtyper"

\begin{tabular}{|c|c|c|}
\hline \multicolumn{1}{|c|}{ »ldealtyp« } & \multicolumn{2}{c|}{ Sannolikhet } \\
\hline $\begin{array}{c}\text { 45-årig svensk som är samboende utan barn. Universitetsutbildad med en } \\
\text { disponibel inkomst på I 20 000 kronor. }\end{array}$ & $1986-87$ & $1996-98$ \\
\hline $\begin{array}{c}\text { 45-årig som är utländsk medborgare, samboende utan barn. Universitetsutbil- } \\
\text { dad med en disponibel inkomst på I 20 000 kronor. }\end{array}$ & 1,6 & 1,0 \\
\hline $\begin{array}{c}\text { 45-årig som är utländsk medborgare, samboende utan barn. Enbart grund- } \\
\text { skola och en disponibel inkomst på 85 000 kronor.Arbetslös och 30\% } \\
\text { transfereringsberoende }\end{array}$ & 17,5 & 8,6 \\
\hline $\begin{array}{c}\text { 27-årig som är utländsk medborgare, ensamstående utan barn. Enbart grund- } \\
\text { skola och en disponibel inkomst på 85 000 kronor.Arbetslös och 30\% } \\
\text { transfereringsberoende }\end{array}$ & 61,9 & 25,1 \\
\hline $\begin{array}{c}\text { 27-årig som är utländsk medborgare, ensamstående utan barn. Enbart grund- } \\
\text { skola och en disponibel inkomst på 60 000 kronor.Arbetslös samt ett } \\
\text { halvt års arbetslöshetserfarenhet och 70\% transfereringsberoende }\end{array}$ & 96,4 & 68,2 \\
\hline $\begin{array}{c}\text { 27-årig som är utländsk medborgare, ensamstående utan barn. Enbart grund- } \\
\text { skola och en disponibel inkomst på 60 000 kronor.Arbetslös samt ett halvt } \\
\text { års arbetslöshetserfarenhet och I00\% transfereringsberoende, bostads- } \\
\text { bidrag }\end{array}$ & 99,6 & 95,2 \\
\hline
\end{tabular}


höga arbetslöshet tycks socialbidraget $\mathrm{i}$ allt större utsträckning ha blivit ett generellt inkomststöd för människor vars enda problem är att de, främst på grund av arbetslöshet, saknar de nödvändiga inkomsterna.

Höjda transfereringar skulle minska bidragstagandet. Men, ett socialförsäkringssystem kan inte utformas för att till varje pris minska andelen socialbidragstagare. För det första skulle sådana reformer av de mer generella delarna av transfereringssystemen bli mycket kostsamma. Merparten av de hushåll som skulle dra nytta av mer generösa transfereringar är hur som helst inte berörda av socialbidragen. För det andra är det uppenbart att det främst är via minskad arbetslöshet och ökad sysselsättningsgrad, inte minst bland ungdomar, invandrare och utländska medborgare, som bidragstagandet kan förmås att minska. Att utforma skatter och transfereringssystem på ett sätt som i möjligaste mån befordrar efterfrågan på arbetskraft samt att se till att den potentiella arbetskraften har de kvalifikationer som krävs, alternativt värdera de kvalifikationer de faktiskt har på rätt sätt, synes vara den mest centrala uppgiften för att minska beroendet av socialbidrag.

Samtidigt måste frågan ställas varför individer i vissa kategorier har en förhöjd risk att uppbära bidrag även efter det att hänsyn tagits till arbetslöshet, inkomster och annat. Bakom exempelvis antagandet om att medelålders personer med högt transfereringsberoende har en större sannolikhet att uppbära bidrag än andra låg en idé om att detta förhållande indikerade mer komplexa individuella problem. Det finns inget i de analyser som gjorts som motsäger detta vilket i sin tur leder till konklusionen att det inte bara är konjunkturer och allmänna försörjningsproblem som leder till bidragstagande. Bland bidragstagarna finns det uppenbarligen individer som kräver mer stöd än bara pengar vilket pekar på vikten av att bidragsgivandet kan kombineras med ett kvalificerat socialt arbete. Något som naturligtvis försvåras under perioder där socialbidragen på grund av extern press allt mer får rollen som kompletterande socialförsäkring.

Att de stora ekonomiska problem som drabbade landet under 1990-talet förklarar en stor del av variationen i socialbidragstagandet visar inte minst de analyser som presenterats här. Som nämndes i inledningen tycks det dock även finnas en underliggande trend mot ett tilltagande bidragstagande, vid varje högkonjunktur sjunker bidragstagandet tillbaka men inte ända ner till de nivåer som rådde vid den förra högkonjunkturen (se Diagram 1). Om detta mönster på ett avgörande sätt kommer att brytas i och med den nedgång av bidragstagandet som började i slutet av 90-talet är för tidigt att sia om. Vad kan ligga bakom denna utveckling? Möjligen är det så att synen på socialbidraget har förändrats. Ser vi i ett längre historiskt perspektiv är det definitivt så. I CSA:s barndom var all form av fattighjälp kopplat till en uppenbar stigmatisering som underströks av det faktum att den som mottog hjälp de facto omyndighetsförklarades. Även dagens bidragstagande är dock förknippat med stigmatisering. I en undersökning genomförd 1998 instämde nästan 40 procent av den vuxna befolkningen i påståendet att "många som söker socialbidrag är utslagna", knappt 20 procent höll med om att många bidragstagare egentligen

Björn Halleröd: Varför får folk socialbidrag? Analys av socialbidragstagandets bestämningsfaktorer. 
inte är fattiga, nästan 30 procent ansåg att många får bidrag på grund av fusk och drygt 20 procent instämde i påståendet att "många socialbidragstagare är lata och saknar ambitioner att själva förändra sin situation«. ${ }^{11}$ Ett intressant faktum i sammanhanget är att det är bland de äldre som dessa negativa attityder är mest förekommande. På samma sätt visar undersökningar om ungdomars värderingar att yngre människor i större utsträckning än äldre tycker att det är rätt att systematiskt planera för att utnyttja sociala förmåner så mycket som möjligt samt att acceptansen för fusk med bidrag är högre bland de yngre (Ungdomsstyrelsen 1998: 64-66). Om detta är ett uttryck för långsiktiga attitydförändringar går naturligtvis inte att uttala sig om, det kan ju lika gärna vara utslag för mer eller mindre konstanta ålderskillnader. Det är dock givet att en mindre negativ inställning i sig kan driva en utveckling mot ett allt mer utbrett bidragstagande. Om det är bra eller dåligt beror i slutändan på de effekter som bidragstagandet har för den enskilde bidragstagaren och för samhället i stort. A ena sidan kan det argumenteras för att bidraget överutnyttjas och att män- niskor väljer bidrag istället för arbete. I förlängningen leder ett sådant beteende till att individer riskerar att passiviseras $i$ ett långsiktigt beroendeförhållande samtidigt som samhället som helhet drabbas av produktionsförluster. Mer strikta normer, hårdare prövning och krav på motprestationer framstår då som en framkomlig väg för att bryta utvecklingen. $\AA$ andra sidan kan en trendmässig ökning av andelen bidragstagare vara ett uttryck för att människor som tidigare avstått från att söka bidrag på grund av just stigma eller okunskap i allt större utsträckning begär de bidrag som de har rätt till för att uppnå en skälig levnadsstandard, allt i enlighet med de intentioner som fanns i 1982 års socialtjänstlag. Om målet är att alla skall ha en sådan standard kanske ett ökat bidragstagandet i grunden skall ses som en god och önskvärd utveckling. Som vanligt måste det konstateras att verkligheten är mångfasetterad och komplex och att vår kunskap är bristfällig. Således behövs, som alltid, mer forskning vilket konkret betyder att det kunskapssökande CSA inledde för hundra år sedan måste fortgå och fördjupas i takt med att samhället förändras.

11 Uppgifterna är hämtade från 1998 års ULF som vid sidan av de mer traditionella ULF frågorna även innehöll ett batteri med attitydfrågor. Resultaten som presenteras baseras på egna beräkningar. 


\section{Referenser}

Bergmark, Åke (2000) "Socialbidragen under 1990-talet» i Bergmark, Å., red,: Välfärd och försörjning. Stockholm: Fritzes.

Gustafsson, Björn (1984) En bok om fattigdom. Lund: Studentlitteratur.

Halleröd, Björn (1991) Den svenska fattigdomen. Lund: Arkiv.

Halleröd, Björn (1995) "Making Ends Meet: Perception of Poverty in Sweden." Scandinavian Journal of Social Welfare, 4, 174-189.

Halleröd, Björn (1999) „Economic Standard of Living: A Longitudinal Analysis of the Economic Standard among Swedes 1979 - 1995." European Societies 1: 391-418.

Halleröd, Björn (2000) "Socialbidragstagande och fattigdom"i Puide, A., red,: Socialbidrag $i$ forskning och i praktik. Göteborg: Gothia.

Halleröd, Björn (2001) „Employment Positions, Class and Economic Hardship" i Furåker, B., red,: Employment, Unemployment, Marginalization: Studies in Contemporary Labour Markets. Stockholm: Almqvist and Wiksell International.

Hammarstedt, Mats (2000) "The Recipt of Transfer Payments by Immigrants in Sweden." International Migration 38: 239-266.

Hellevik, Ottar (1992) Introduction to Causal Analysis. Oslo: Scandinavian University Press.

Hydén, Lars.-Christer, Kyhle Westmark, Pia. och Stenberg, Sten-Åke (1995) Att besluta om socialbidrag, en studie i 11 kommuner. Stockholm: CUS.

Häll, Lars. and Vogel, Joachim (1997) Välfärd och ojämlikhet i 20-års perspektiv 1975-1995. Örebro: Statistiska Centralbyrån, Rapport 91.

Johansson, Håkan (2000) "Ungdomar med socialbidrag - ett politiskt problem för 1990-talet“ i Bergmark, Å., red,: Välfärd och försörjning. Stockholm: Fritzes.
Korpi, Walter (1971) Fattigdom i välfärden. Stockholm: Tidens förlag.

Palme, Joachim (2000) "Socialförsäkringar och kontanta familjestöd» i Bergmark, Å., red,: Välfärd och försörjning. Stockholm: Fritzes.

Rauhut, Daniel (2002) Fattigvård, socialbidragstagande och synen på fattigdom i Sverige 19181997. Lund: Lund University.

Ribe, Martin (1999) Oddskvoter berättar. Väl färdsbulletinen: 14-15.

Salonen, Tapio (2000) „Ungdomars socialbidragstagande och försårjningssvårigheter under 1990-talet» i Bergmark, A., red,: Välfärd och försörjning. Stockholm: Fritzes.

Stattin, Mikael (1998) Yrke, yrkesförändring och utslagning frän arbetsmarknaden, Department of Sociology. Umeå: Umeå University.

Stenberg, Sten.-Åke (1998) „Unemployment and Economic Hardship; A Combined Macro- and Micro-level Analysis of the Relationship between Unemployment and Means-Tested Social Assistance in Sweden." European Sociological Review 14: 1-13.

Strandh, Mattias (2000) Varying Unemployment Experience? The Economy and Mental WellBeing. Umeå: Department of Sociology, Umeå University.

Ungdomsstyrelsen (1998) Ny tid, nya tankar? Ungdomars värderingar och framtidstro. Stockholm: Ungdomsstyrelsen.

Åberg, Rune (2002) „Unemployment persistance, overeducation and employment chances of the less educated." European Sociological Review forthcomming.

Åberg, Rune, Strandh, Mattias, Nordenmark, Mikael och Bolinder, Margareta (1997). "Massarbetslösheten på 90-talet» i Häll, J., och J. Vogel, red,: Välfärd och ojämlikhet i 20-års perspektiv 1975-1995. Örebro: Statistiska Centralbyrån, Rapport 91.

Björn Halleröd: Varför får folk socialbidrag? Analys av socialbidragstagandets bestämningsfaktorer. 


\section{Summary \\ Why do people receive social assistance?}

Why do people receive social assistance? This paper aims to give at least a partial answer to this question. Two periods, the mid 1980s and the mid 1990s, are compared, both representing periods when Sweden was recovering from an economic downturn, the difference being that the recession of the 1990s was considerably more dramatic. The data were drawn from the Swedish Survey of Living Conditions and the working sample restricted to nonpensioners within the age span 20 to 64 . Unemployment was, of course, found to be of major importance, and social assistance, especially during the 1990s, plays the role of additional unemployment insurance. In particular immigrants were dependent on assistance because of unemployment. A large and increasing share of the recipients of assistance were also dependent on other types of transfers such as housing benefit, unemployment and sickness insurance etc. The effect was that cuts in these programmes to some extent caused increased pressure on the social assistance system.

Even though unemployment was skyrocketing in the early nineties, the probability among the unemployed of receiving assistance was generally lower than in the eighties, the reason being that the unemployed group was more "normalized", having only one problem, i.e., unemployment. Another change over time was that income has an increasing impact, reflecting the increasing income disparity. Otherwise, no fundamental changes over time were visible. Even after controlling for a large number of economic, demographic and individual circumstances, the risk of being dependent on social assistance was significantly higher among foreign citizens, people with impaired health and a group of middle-aged people with extensive transfer dependency, indicating that people in these categories were facing problems of greater complexity. At the same time, the assistance risk decreased with age, indicating either generational differences in the utilization of social benefits, or a constant age difference, i.e. people change their behaviour and/or improve their ability to handle harsh economic conditions as they get older. Further research is needed to shed light on which of these explanations is the most likely. 